短報〔Note

\title{
千曲川における大量発生昆虫オオシロカゲロウの流程分布
}

\author{
関根一希 ${ }^{1)} \cdot$ 末吉正尚 $^{2)} \cdot$ 東城幸治 $^{3,4) *}$
}

\section{Current distribution of the polymitarcyid mayfly Ephoron shigae in the Chikuma-gawa River}

\author{
Kazuki SEKINÉ ${ }^{1)}$, Masanao SUEYOSHI ${ }^{2)}$, and Koji TOJO ${ }^{3,4)}$
}

\begin{abstract}
The polymitarcyid mayfly Ephoron shigae is widely distributed in Japan, and inhabits burrows in gravel riverbeds in the mid and lower regions of rivers. This mayfly is renowned for synchronized mass emergences at dusk in early autumn, which have been frequently observed in various Japanese rivers since the 1970s. Although much geographic documentation of synchronized mass emergence has accumulated for major populations, there is not much information for smaller populations. There are a number of reasons the full distribution of this mayfly is not well known, including; 1) the comparatively short period of the adult stage (shorter than two hours), 2) the short emergence season (one or several weeks per year), 3) the short nymphal season (E. shigae remains as diapause stage eggs from autumn to spring), and 4) the typical habitats are below deep water riverbeds in the mid to lower reaches of comparatively large rivers. In this study, we investigated the current distribution range (i.e., the geographic distribution range along the river' s course) of the mayfly E. shigae in the Chikuma-gawa River (Nagano Prefecture), where it is considered to be one of the largest continuously extant meta-populations of this mayfly. The first record of mass emergence of this mayfly in the Chikuma-gawa River was reported in the novel entitled "Hounen-mushi" written in 1928 by Shiga Naoya, and has since been observed for more than 80 years. In the results of our research, it was revealed that $E$. shigae inhabits an extended distribution range from the city of Ueda to the town of Obuse. Further, we observed high mayfly density and high biomass in a region around the Heiwabashi and Awasa-bashi bridges. From these areas, the density, body size and the biomass of the mayflies decreased gradually in both the upstream and downstream zones. This result is consistent with a previous study investigating the distribution of the adult stage of this species. However, contrary to the previous study, we found many more nymphs at the downstream sites (the Yashima-bashi and Obuse-bashi bridges) than at the Sai-gawa tributary merge point. However, the collected individuals at these two downstream sites were markedly smaller in size. The
\end{abstract}

\footnotetext{
1) 日本学術振興会特別研究員 PD (独立行政法人農業生物資源研究所昆虫科学研究領域) ₹ 305-8634つくば市大わし 1-2 Research Fellow of the Japan Society for the Promotion of Science (Division of Insect Sciences, National Institute of Agrobiological Sciences) 1-2, Owashi, Tsukuba, Ibaraki 305-8634, Japan

2) 北海道大学農学院環境資源学専攻 $\overline{\mathbf{T}}$ 060-8589 札幌市北区北 9 条西 9 Graduate School of Agriculture, Hokkaido University, Kita 9 Nishi 9 , Kita-ku, Sapporo 060-8589, Japan

3) 信州大学理学生物科学科 $\mathbf{T} 390-8621$ 松本市旭 3-1-1 Department of Biology, Faculty of Science, Shinshu University, Asahi 3-1-1, Matsumoto, Nagano 390-8621, Japan

4) 信州大学山岳科学総合研究所 ⿳ 390-8621 松本市旭 3-1-1 Institute of Mountain Science, Shinshu University, Asahi 3-1-1, Matsumoto, Nagano 390-8621, Japan

（連絡先＼cjkstart東城幸治ktojo@ @hinshu-u.ac.jp）
} 
inflow of Sai-gawa River into the Chikuma-gawa River is comparatively oligotrophic and may provide fewer food resources for the detritus-feeding nymphs.

Key words: aquatic insect, Ephemeroptera, geographic parthenogenesis, macrobenthos, synchronized mass emergence

\section{摘 要}

オオシロカゲロウは国内広域の河川中・下流域に棲息し，幼生は河床の砂碟に潜って生活する。羽化 は初秋 (1 週間から数週間程度 ) の日没後にみられるが, 極めて同調性の高い羽化であり, 交尾飛翔・群 飛が認められ, 大発生に至ることもある水生昆虫である。1970 年代から本種における大発生は日本各地 の河川において報告されてきたが，本種の棲息状況に関しては，羽化個体において評価されるに留まっ ており, 河川内の詳しい分布は十分には把握されていないのが現状である。理由としては，1）短い亜成 虫・成虫期間 (長くても 2 時間程度 )，2）短い羽化時期，3）短い幼生期間 ( 約半年を休眠卵で過ごす), 4）典型的なハビタットは比較的大きな河川の中下流で，かつ河床の砂碩に潜る生活型であることがあげ られる。このような状況から, 本研究では, 本種の大発生が 1928 年と最も古い記録 ( 志賀直哉の小説「豊 年蟲」としての記録）として残され，現在も規模の大きな発生が続いていて，個体群規模も大きな長野 県・千曲川を調査地として，幼生ステージにおける分布調査を実施した。その結果，羽化量調査による 先行研究と同様, 最も多くの羽化個体が認められた平和橋-粟佐橋調査区において, 体サイズの大きい 幼生が高い個体密度で棲息することが確認された。一方，平和橋-粟佐橋調査区より上流や下流側では， 個体密度や体サイズなど現存量の低下が認められた。羽化量調査により分布が認められないとされてい た犀川合流地点よりも下流側においても，幼生の棲息が認められた。しかし，幼生の体サイズは小さく， 比較的貧栄養的な犀川の合流により千曲川の污濁度が低下し, 幼生の餌であるデトリタス量が低下した ことに原因があるのかもしれない。

和文キーワード: 水生昆虫, カゲロウ目, 地理的単為生殖, 大型底生生物, 一斉羽化

\section{はじめに}

カゲロウ目の昆虫類は, 成虫期間が短いことで知られ るが，なかでもシロイロカゲロウ科 Polymitarcyidae のオ オシロカゲロウ Ephoron shigae（Takahashi）の成虫期間 は極めて短く, 長い個体でも亜成虫・成虫*期をあわせ て 2 時間程度である。本種は年一化の生活史をもち（Ban et al., 1994; 関根ら , 2007; Watanabe and Ohkita, 2000), 羽 化時期は初秋（9 月上 - 中旬頃）の数日間から長くと も 3 週間ほどで, 羽化時間帯は日没後の 1-2 時間であ る。羽化の同調性は極めて強く, 時には大発生に至る こともある（渡辺ら，1993; Watanabe and Ishiwata, 1997; Watanabe et al., 1999; 東城ら, 2002; Tojo et al., 2006)。2 時間程度の短い亜成虫・成虫期間に空中で交尾を行い, その後, メ又亜成虫は着水し, 水面から卵隗を産下寸る。 このことで胚発生が開始し, 卵塊が解れながら沈水し, それぞれの卵が河床の砂碟に付着して胚発生を続ける (中村, 1985)。産卵後約一月で, ほぼ胚発生の最終ステー
ジにまで進行すると, 一旦, 発生が停止し休眠状態とな る（中村，1985; Nakamura et al., 1999)。そのまま休眠卵 として越冬し, 翌年の早春 ( 2 月末-4 月初め) に休眠が 解除されると, 幼生が孵化し ( 渡辺ら, 1993; Watanabe and Ohkita, 2000; 関根ら, 2007), はまり石のある砂碟質 の河床にU 字状の巣穴を掘り, デトリタスを慨とする掘 潜型の濾過食者となる（野崎, 1983; 蓮田, 1989)。

本種の体長は約 $20 \mathrm{~mm}$ と国内で最も大きいカゲロウ の一種であり, 乳白色をした亜成虫・成虫は薄暗い中で 目立つ姿をしている。強い走光性をもつことから，しば しば川沿い, あるいは橋上の水銀灯などの周りに群飛し, その様子は吹雪のような光景になることもある。メス亜 成虫の歩脚はいずれも退化的で短く, 一旦, 地面に降り 立つと再び飛び上がることが困難である。これは，2 時 間程度の成虫期間であるため, 空中で行われる交尾も含 めて空中のみでの生活スタイルに特化した適応の一つで あると考えられる。このため, 本種の死骸や卵塊が川沿 いの道路あるいは橋上に積もり, 自動車のスリップ事故 
の原因となることもあるため，大量羽化がみられるよう な河川においては，しばしばメディアにも取り挙げられ てきた。

このようなオオシロカゲロウ亜成虫・成虫の大量羽 化は，1970年代から福島県をはじめとする多くの河 川で報告されており（e.g., 塩山, 1978; Ishiwata, 1996; Watanabe and Ishiwata, 1997), ダムによる水量の安定化 や餌となるデトリタスの堆積に原因があると考えられ てきた（渡辺ら, 1993; 渡辺 , 1996; 伴, 1997; 千葉, 2000, 2010)。しかし，本種の大量羽化の記録はかなり古くか らあり, 1928 年に文豪・志賀直哉によって, 長野県上 田・戸倉付近を舞台に執筆された小説「豊年蟲」には, 上田と戸倉・上山田地域の千曲川で大発生するカゲロウ （豊年蟲）のことが詳述されている。この作品には, 実 に詳細な形態や生態に関する描写がなされており,この
カゲロウ（豊年蟲）がオオシロカゲロウであることは間 違いない。そして, 当時からは 80 年以上も経過した現 在においても, 千曲川ではオオシロカゲロウの大量羽化 が認められている。千曲川個体群の分布は, 高度経済成 長期による人為的な干渉にも影響されていると考えられ るが，従来の千曲川の河道特性とも関連があるのかもし れない。

本種の棲息状況に関しては，1）短い亜成虫・成虫期 間 (長くても 2 時間程度 ), 2) 短い羽化時期, 3) 短い 幼生期間 ( 約半年を休眠卵で過ごす)，4）典型的なハビ タットは比較的大きな河川の中・下流で, かつ河床の砂 礫に潜る生活型であり，比較的調査が困難であることか ら，容易な調査が可能である羽化個体において評価され るに留まっている。千曲川においても中村 (1999)によ り, 上田盆地から長野盆地までの本種成虫の羽化量調査
A

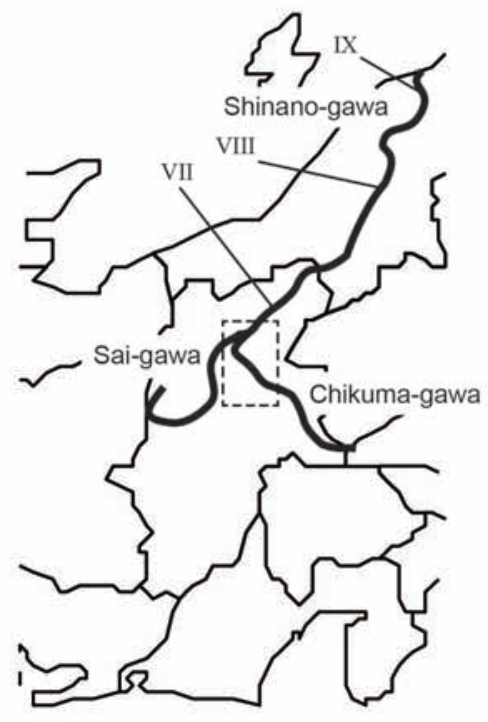

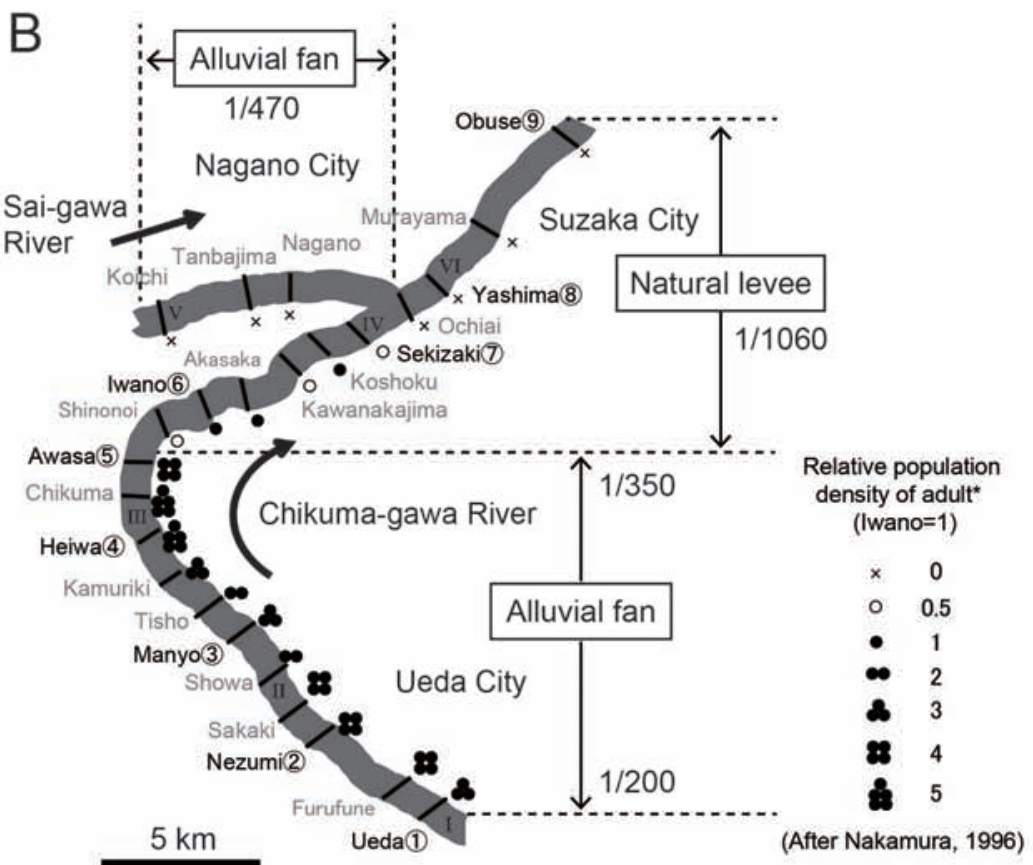

Fig. 1. Map showing the location of the Chikuma-gawa River in the Shinano-gawa River basin (A); and the relative population density* of adult Ephoron shigae observed in the previous study (Nakamura, 1996) (B). Detailed view of area within dashed lines in Fig. 1A. We investigated nine sites marked (1)-9) included in a previous study (Nakamura, 1996). Roman numerals indicate the locations observing BOD (biochemical oxygen demand) and COD (chemical oxygen demand) data referred to in Fig. 5. I: the Ikuta observatory, II: the Kogai-bashi observatory, III: the Chikuma-bashi observatory, IV: the Sekizaki-bashi observatory, V: the Koichi-bashi observatory, VI: the Yashima-bashi observatory, VII: the Tachigahana-bashi observatory, VIII: the Chosei-bashi observatory, IX: the Heisei-ohashi observatory. Fractions indicate stream gradients.

図 1 信濃川水系千曲川の地図 (A) と先行研究 (中村, 1996) におけるオオシロカゲロウ成虫の発生量 (B). A における破線枠部 の拡大図を B に示す. 図内の地名は中村 (1996) の調査地 24 地点であり, そのうち今回の調査地 9 地点を(1)-(9)で示す. 番 号 I から IX は図 5 において扱われた水質データ（BOD および COD）が測定された観測所を示す. I: 生田観測所, II: 笄橋観 測所, III: 千曲橋観測所, IV: 関崎橋観測所, V: 小市橋観測所, VI: 屋島橋観測所, VII: 立ヶ花橋観測所, VIII: 長生橋観測所, IX: 平成大橋観測所. 分数は河川勾配を示す.

*岩野橋の成虫発生量を 1 とした時の相対量. 
が 24 地点でなされており (Fig. 1), 本種成虫が認めら れたのは上田市・上田橋から長野市・関崎橋にかけての 千曲川（約 $32 \mathrm{~km}$ ）に限定されていること, 千曲川最大 の支川である犀川の入点より下流側では全く認められな いこと（犀川においても認められていないこと）が報告 されている。しかし，これらの調査は成虫を対象とした ものであり，また，橋上に設置された照明の強度や水面 からの設置距離（高さ）によって影響される可能性も考 えられる。総延長 $360 \mathrm{~km}$ を超え, 本邦最長の河川であ る千曲川 ( 信濃川 ) の中でも, わずか 1 割程度の流程に だけ棲息する本種の分布要因については，以前から課題 として挙げられつつも未解決のままである。

そこで, 千曲川におけるオオシロカゲロウの局所的分 布の謎に迫るため, 先ず，千曲川における本種幼生の分 布を調査し，より正確なオオシロカゲロウの分布状況を 明らかにすることを目的とした。

\section{調査地点および方法}

本研究では, 長野県・千曲川を調査河川とし, 中村 （1999）の調査地を含めた上田盆地から長野盆地までの 流程内に 9 つの調査地区を設定した。各調査地区は, 上流側から (1) 上田市 -上田橋地区 (N 36 23' 47.44", E $138^{\circ} 14^{\prime} 38.76^{\prime \prime}$ ), (2)埴科郡坂城町 - 鼠橋地区 (N 36 $25^{\prime}$ $37.75^{\prime \prime}$, E $\left.138^{\circ} 11^{\prime} 22.01 "\right)$, (3)千曲市・万葉橋地区 (N 36 '28' 44.84", E $\left.138^{\circ} 88^{\prime} 53.73 "\right)$, (4)千曲市・平和橋地区 (N $36^{\circ} 30^{\prime} 59.15^{\prime \prime}$, E $\left.138^{\circ} 6^{\prime} 43.69^{\prime \prime}\right)$, (5)千曲市・粟佐橋地区 (N $36^{\circ} 32^{\prime} 24.69^{\prime \prime}$, E $\left.138^{\circ} 6^{\prime} 55.66^{\prime \prime}\right)$, 6)長野市・岩野橋地区 (N $36^{\circ} 33^{\prime} 42.81^{\prime \prime}$, E $138^{\circ} 9^{\prime} 24.98^{\prime \prime}$ ), (7)長野市・関崎橋地区 （N 36 36' 21.24", E 138 13' 25.22" ), 8長野市・屋島橋 地区 (N 36 38' 24.18", E $\left.138^{\circ} 15^{\prime} 29.28^{\prime \prime}\right)$, そして(9)小布 施町・小布施橋地区 (N 36 42' 20.61", E 138 17' 46.47") である（Fig. 1, 2)。 8)屋島橋地区と9)小布施橋地区の 2
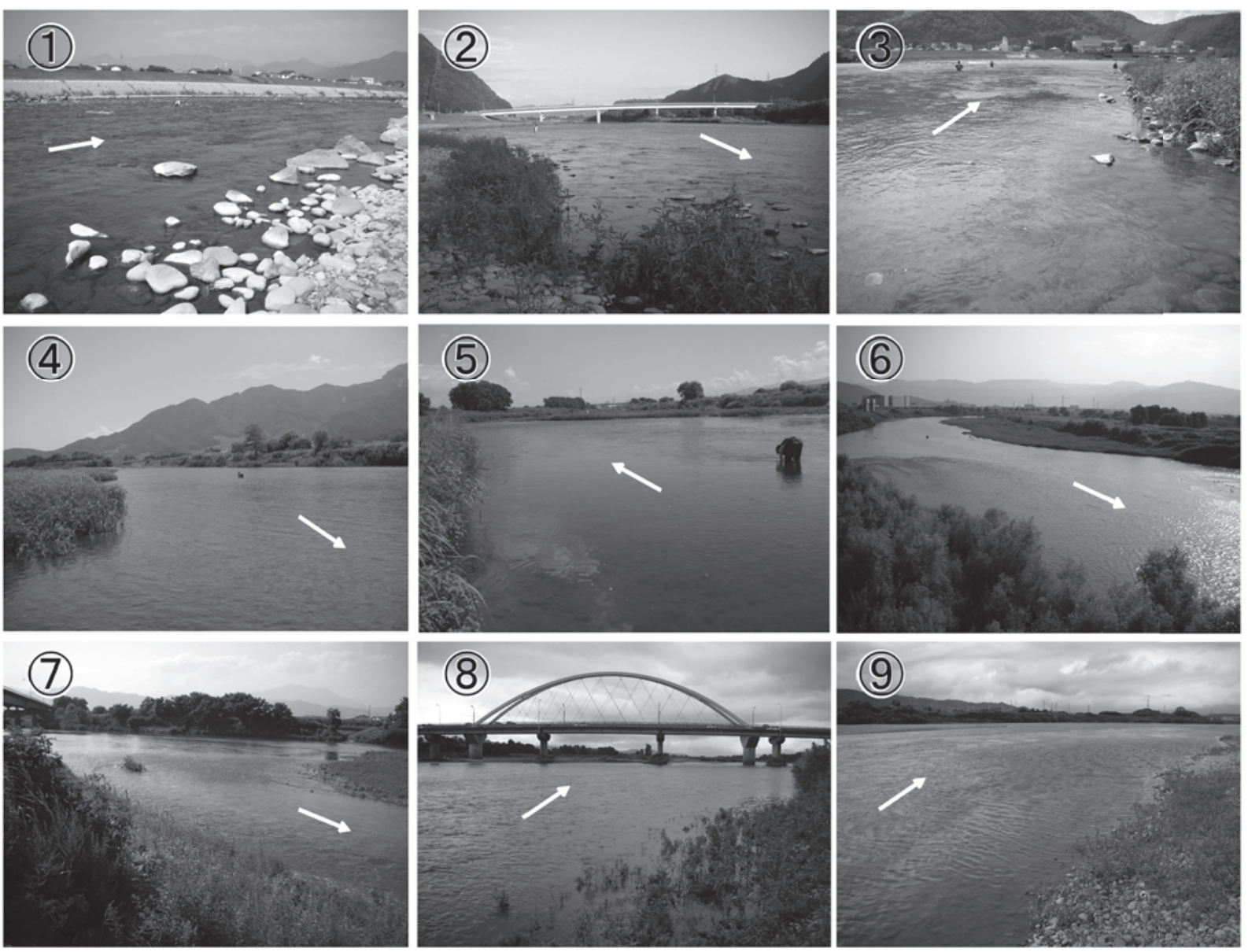

Fig. 2. The landscape of each study area along the Chikuma-gawa River. (1): the Ueda-bashi research site, (2): the Nezumi-bashi research site, (3) : the Manyo-bashi research site, (4) : the Heiwa-bashi research site, (5) : the Awasa-bashi research site, (6) : the Iwano-bashi research site, (7) : the Sekizaki-bashi research site, (8) : the Yashima-bashi research site, (9) : the Obuse-bashi research site.

図 2 千曲川における各調査地区の景観. (1): 上田橋調査地区, (2): 鼠橋調査地区, (3): 万葉橋調查地区, (4): 平和橋調査地区, (5): 粟佐橋調查地区, (6) : 岩野橋調査地区, (7) : 関崎橋調查地区, (8) : 屋島橋調查地区, (9) : 小布施橋調査地区. 
つの調査地区は，千曲川最大の支川である犀川が流入す る地点よりも下流部にあたる。千曲川における本調查地 の河川地形については, 上田 (河川勾配 1/200) -粟佐橋 地区 (1/350) が扇状地帯に該当し, 粟佐-小布施橋地区 は自然堤防帯（1/1060）であり河川の蛇行が繰り返され る( 国土交通省北陸地方整備局，1997）。

雨による大規模な増水が生じていなかった 2007 年 7 月 $28-30$ 日の 3 日間を調查日として, 各調査区で 10 区 画のコドラート $(300 \times 300 \mathrm{~mm})$ 一体型のサーバーネッ 卜（離合社製; NGG42: 目合 $0.450 \mathrm{~mm}$ ) 内で深さ約 300 $\mathrm{mm}$ までのはまり石を掘り返す定量調查を行ない, 10 回 のコドラート採集において, 幼生が認められたコドラー トの割合 (幼生の出現率) および個体密度を調べた。各 調査地区におけるコドラート設置区画の選定に際して は, 各地区における典型的な瀬ハビタットからランダム に 10 区画を選定したが，コドラート調査である都合上， 水深や流速に関しては, ある一定の条件内に限定せざる を得なかった。しかし, 大型カゲロウとしては十分な個 体数を得ることができた。採集したサンプルについては, 現地にて白バット上で本種幼生をソーティングし， $70 \%$ EtOH で固定して, 実験室へ持ち帰った。実験室におい て, 方眼紙上で幼生の体長㧍よび最大頭幅を測定し, 電 子天秤 (A\&D 社 製, FX-300i) により各幼生個体の湿重 量を計測した。それぞれのコドラート採集地点について は, サンプル採集の直前に水深を, 電磁流速計 (KENEK 社製，VE10）により水深 60\% の流速を計測した。また, 採集地点の河床に方形枠を置き, 水中カメラ(オリンパ ス社製， $\mu$ Tough）により撮影・記録した。撮影した河

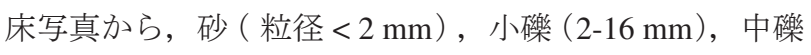
(17-64 mm), 大磁 $(65-256 \mathrm{~mm})$, 巨硆 $(257-1024 \mathrm{~mm})$ としてそれぞれの被度を測り, 底質粗度 $(=$ 砂被度 $\times 1$ + 小碟被度 $\times 2+$ 中碟被度 $\times 3+$ 大礫被度 $\times 4+$ 巨碟 $\times 5$; Bain et al., 1985; Inoue and Nakano, 1998）を算出した。

また, 千曲川（信濃川）および䐅川における生物化 学的酸素要求量 biochemical oxygen demand (BOD), 化 学的酸素要求量 chemical oxygen demand (COD), およ び水温の基礎的データに関しては, 国土交通省北陸地 方整備局 I. 生田観測所, II. 笄橋観測所, III. 千曲橋観測 所, IV. 関崎橋観測所, V. 小市橋観測所, VI. 屋島橋観 測所, VII. 立ヶ花橋観測, VIII. 長生橋観測所, IX. 平成 大橋観測所におけるほぼ同時期に測定された観測データ を参照した（Fig. 1)。千曲川個体群におけるオオシロカ ゲロウの孵化期は 3-4 月および习习习化期は 9 月と考光られ るため (渡辺ら, 1993; Watanabe and Ohkita, 2000; 関根ら，
2007), BOD および水温についてはいずれの観測所にお いても 2005 年 3 月 9 日, 4 月 20 日，5月 18 日，6月 15 日, 7 月 20 日, 8 月 17 日, および 9 月 28 日の午前中に 測定された観測データを参照し, 一年間に二度しか測定 されていないCODについては 2005 年 8 月 17 日（観測 所 I-VII）および 2005 年 7 月 20 日（観測所 VIII および IX）の観測データを参照した。

\section{結 果}

各調查地区の物理的環境データとして, 水深, 流速, 河床の底質粗度を計測した (Fig. 3)。各調査地区の水深 は 0.15-0.64 m, 流速は 0.025-0.968 m s, 底質粗度 1.37 - 3.58 ( 鼠橋の河川粗度データなし ) の範囲であった。 各調査区での底質粗度については粟佐橋地区 - 岩野橋地 区間において，流速については万葉橋地区と他全ての 調查地区間において, 水深については鼠橋地区 - 粟佐橋 地区間において有意な違いが認められた $(p<0.05$; SteelDwass test)。いずれの物理的環境データについても, 犀 川の流入地点の上下流間での有意な変化は認められな かった。全調查地区における河床材料は, ほぼ中礫（被 度 0-90\%）と大䃋（0-83\%）により占められていた。ただ し, 上田橋地区や鼠橋地区では, 目視により多数の巨 礫が認められたが（Fig. 2- (1), (2)), 巨碟箇所においては 300-300 mm のコドラート調査ができないため, 本調査 においては対象外とした。

今回調査された千曲川のいずれの地区においてもオ オシロカゲロウ幼生の棲息が認められた (Fig. 4A)。す なわち, 中村 (1999) による羽化成虫の報告とは異なり, 犀川流入地点よりも下流側の地区においてもオオシロカ ゲロウ幼生が棲息していることが明らかとなった。各調 查地区における幼生の出現率は, 平和橋地区および粟佐 橋地区で $100 \%$ と最も高く, 次いで犀川合流後の屋島橋 地区で $80 \%$, 小布施橋地区で $70 \%$ であった。また, 平 和橋地区より上流へ向からほど, 幼生出現率は低くなっ ていった。幼生が認められた物理的環境データについて は, 水深は 0.26-0.51 m, 流速は 0.100-0.968 $\mathrm{m} \mathrm{s}^{-1}$, 底質 粗度 1.40-3.58 の範囲であった。

現存量 ( 湿重量) および個体密度も, 平和橋地区, 粟 佐橋地区および屋島橋地区で高かった（Fig. 4B, C)。い ずれも上田橋地区から粟佐橋地区間では徐々に増加し, 岩野橋地区で減少, 関崎橋地区および屋島橋地区で再び 増加した後, 小布施橋地区で減少した。

体サイズ ( 頭幅 ) については, 粟佐橋地区をピークに 


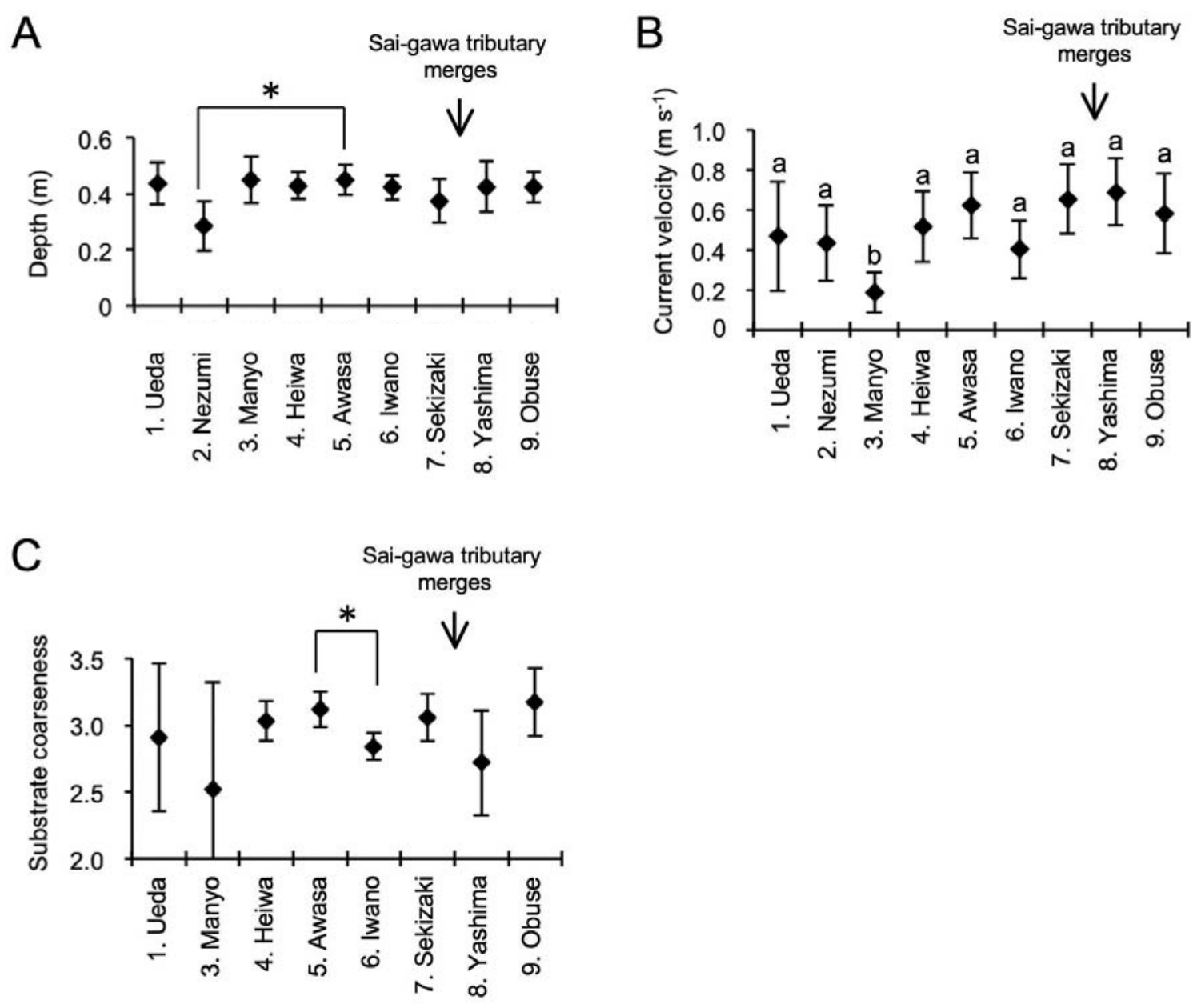

Fig. 3. Depth (A); current velocity at $60 \%$ of total depth (B), substrate coarseness (C) at each research site. Black dots and error bars indicate the mean and standard error at each research site. Asterisks $(*)$ and different letters ( $\mathrm{a}, \mathrm{b})$ indicate significant differences between the research sites $(p<0.05$, Steel-Dwass test).

図 3 各調査地区における水梁 (A), 水深 $60 \%$ 流速 (B), 底質粗度 (C). 黒点およびエラーバーはコドラート地点の平 均值および標準偏差を示す. 有意に異なる調査地区間を*あるいは, 異なるアルファベット $(\mathrm{a}, \mathrm{b})$ で示す $(p<$ 0.05 , Steel-Dwass test).

一山型の分布となった (Fig. 4D, 5)。平和橋および栗佐 橋地区に棲息する幼生の体サイズは関崎橋，屋島橋およ び小布施橋地区に棲息する幼生に対して有意に大きかっ た。また,岩野橋地区における幼生の体サイズも小さかっ たが，採集された個体数が少なく平和橋および栗佐橋 地区の幼生との有意な体サイズの違いは認められなかっ た。オオシロカゲロウは地理的単為生殖種であり，千曲 川の個体群はメスだけで構成される雌性個体群 ( 単為生 殖個体群 ) であることが明らかになっている（Watanabe, 1998; Tojo et al., 2006; 関根 · 東城, 2008; Sekiné and Tojo, 2010)。今回の調査においても，採集された個体はいず れもメス個体であり，体サイズの雌雄差を考慮する必要 はない。一個体当たりの湿重量についても体少イズと同
様の傾向が認められ，平和橋地区および粟佐橋地区にお ける幼生は高い湿重量をもつ一方で, 屋島橋および小布 施橋地区における幼生では有意に低い湿重量が認められ た (Fig. 4E)。

千曲川および犀川の各観測所における 2005 年の BOD および COD 計測データからは, 生田から関崎橋地区ま での区間において, 犀川や信濃川下流部と比べて高い BOD および COD 值が認められる傾向があり（Fig. 6A, B)，オオシロカゲロウの幼生期である 3-9 月における BOD 值については, 観測地点間での有意な違いが認め られた $(p<0.001$, Friedman test $)$ 。Scheffe による多重比 較では, 生田から関崎橋観測地点までの区間と犀川流入 地点より下流部との間に有意な違いは認められなかった 
A

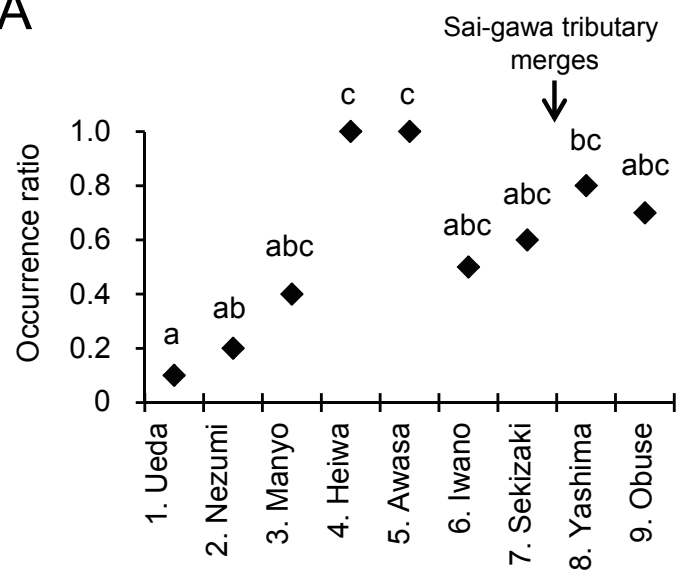

C

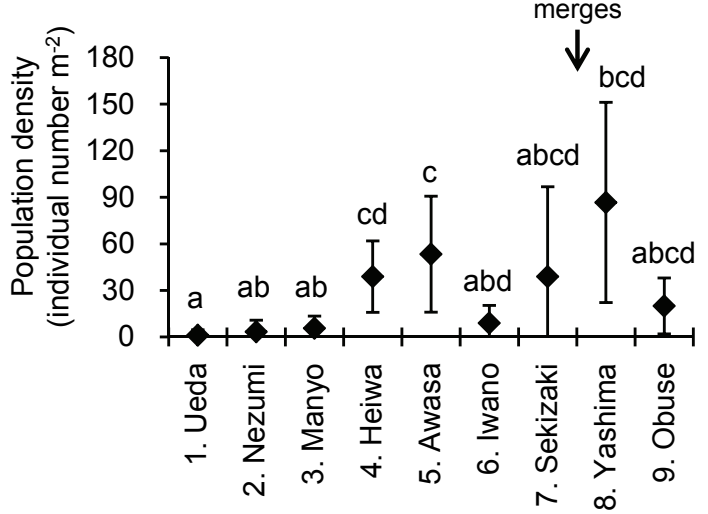

B

B Sai-gawa tributary

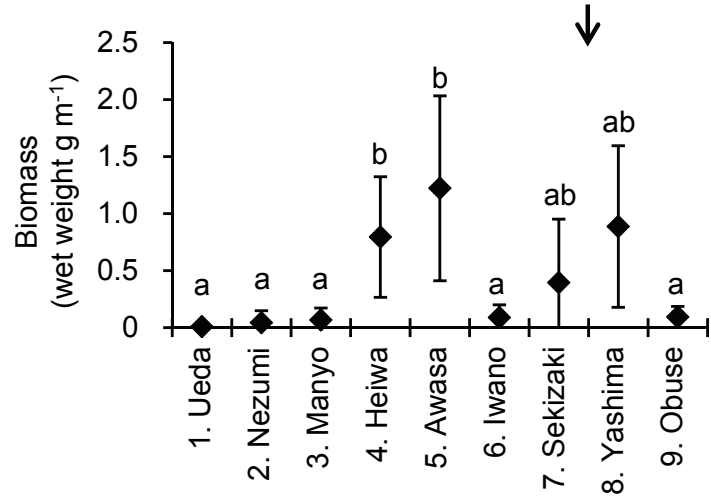

D

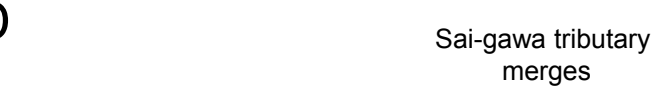

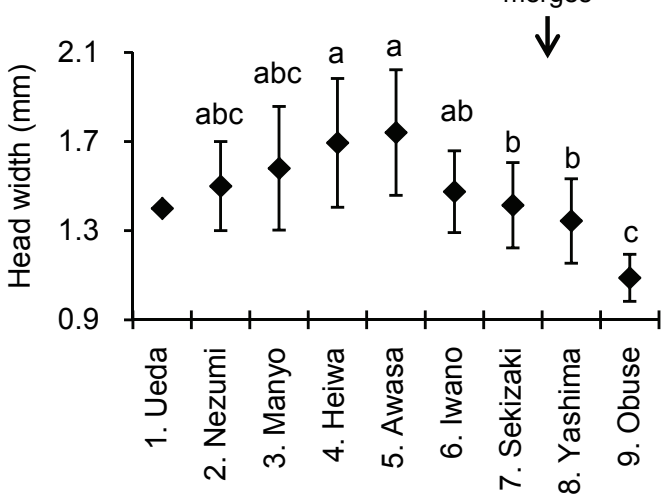

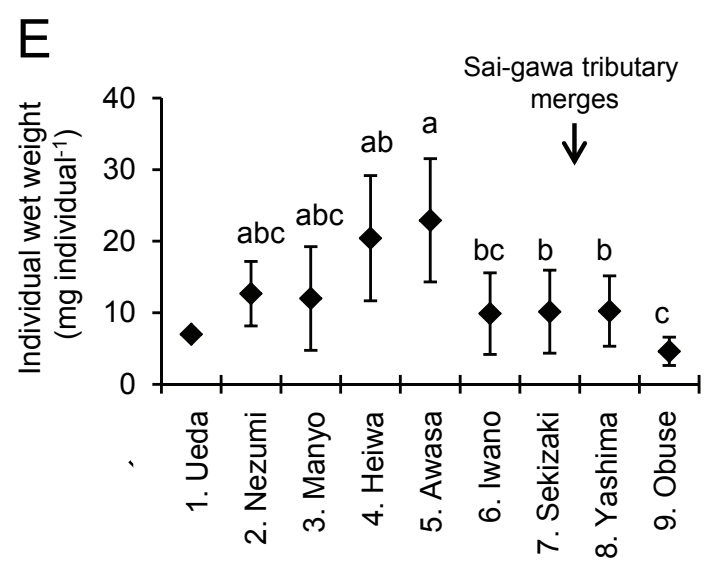

Fig. 4. Occurrence ratio (A); biomass (B); population density (C); size of nymph (D) and wet weight of nymph (E) at each research site. Black dots and error bars indicate the mean and standard error for each research site. The different letters (a, b, c, and d $)$ indicate significant differences between the research sites $(p<0.05$; A: Tukey test, B-E: Steel-Dwass test $)$.

図 4 各調査地区において認められたオオシロカゲロウの出現率 (A), 現存量 (B), 個体密度 (C), 頭幅サイズ (i.e., 個体サイズ ) (D), そして個体湿重量 (E). 黒点およびエラーバーは平均值および標準偏差を示す.有意に異な る調査地区間を異なるアルファベット $(\mathrm{a}, \mathrm{b}, \mathrm{c}, \mathrm{d})$ で示す $(p<0.05$; A: Tukey test, B-E: Steel-Dwass test). 

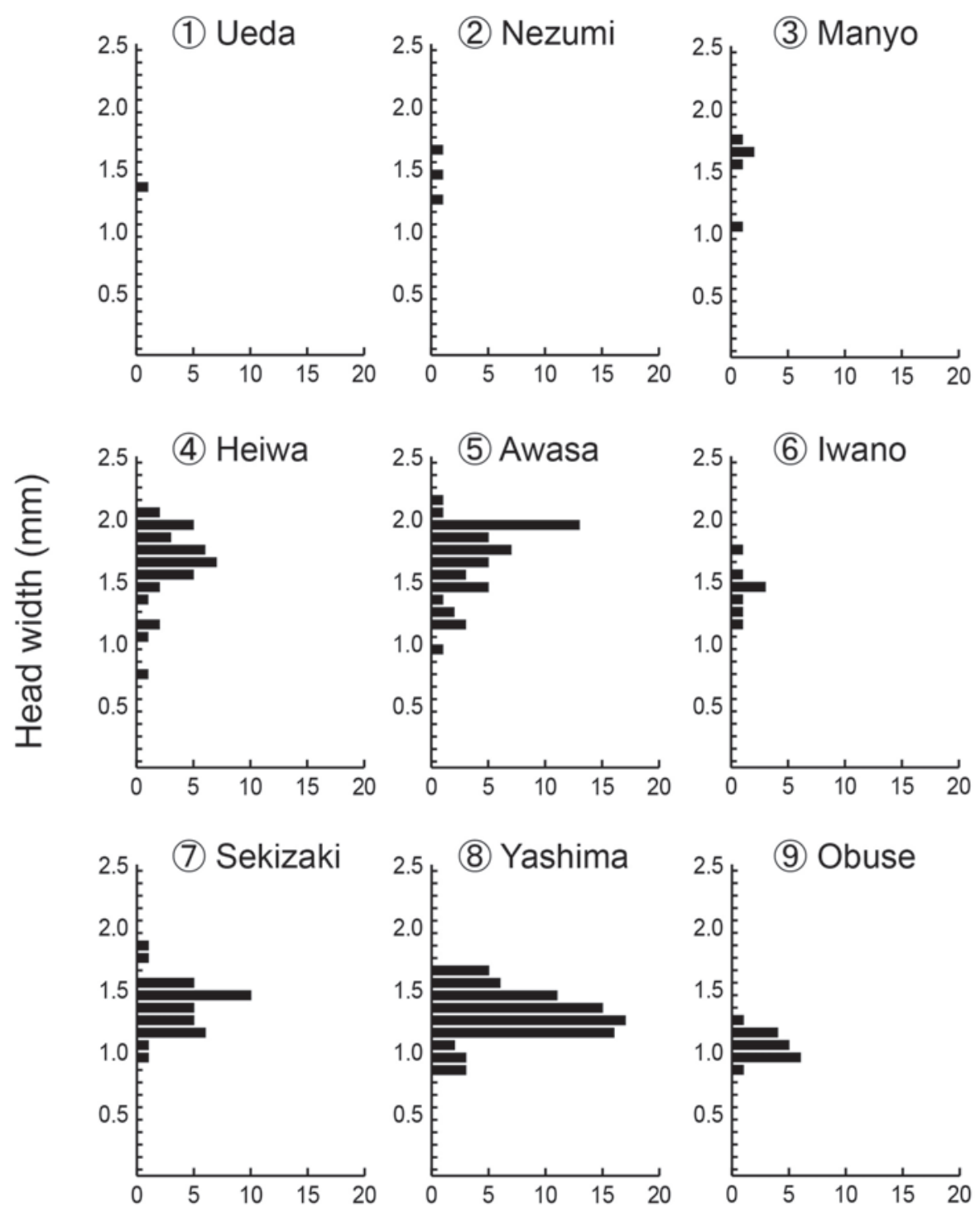

Individual number

Fig. 5. Body size (head width) distribution of all collected Ephoron shigae specimens in each research site. 図 5 各調査定点において採取されたオオシロカゲロウ幼生の体サイズ（頭幅）の分布. 

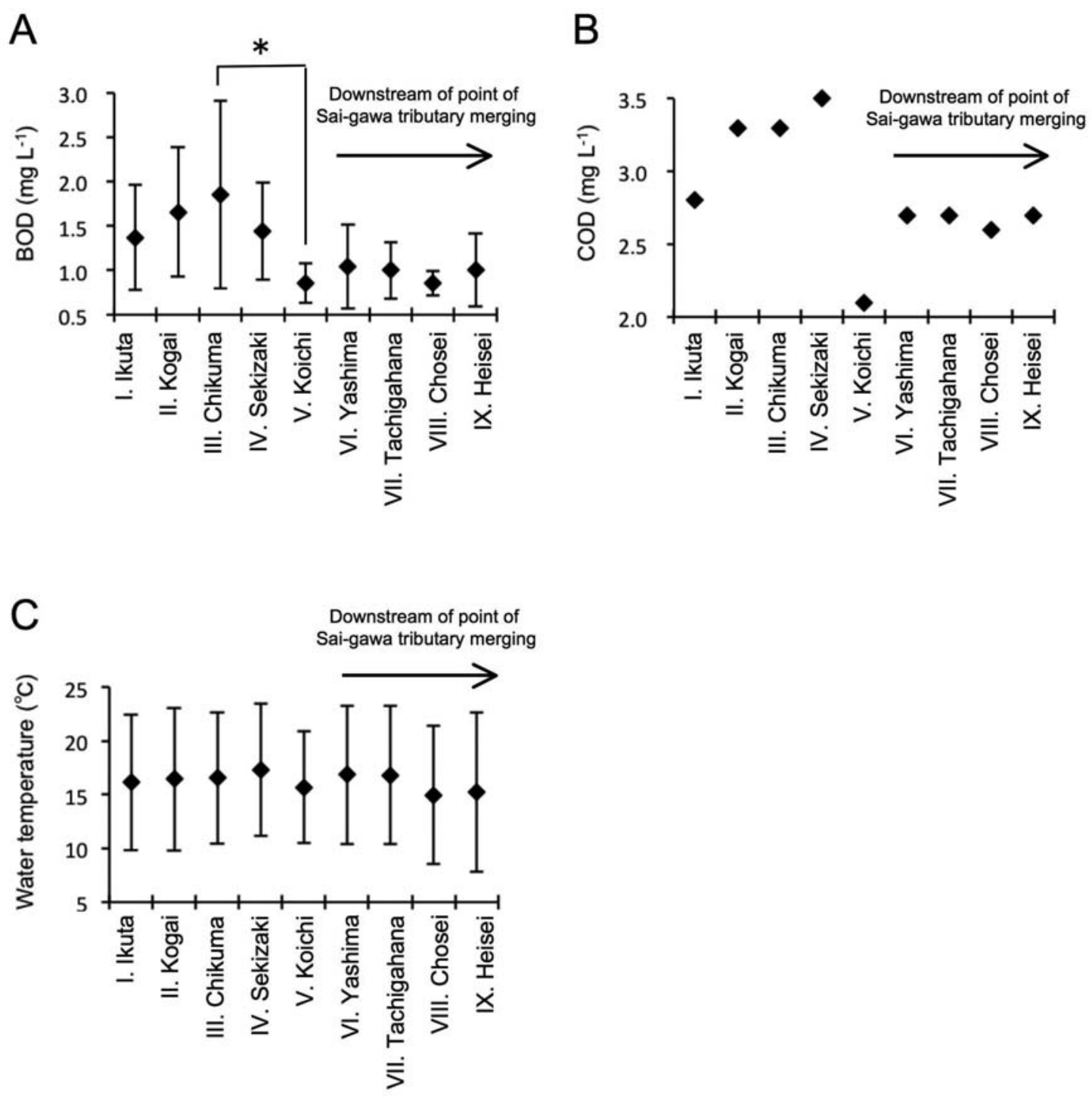

Fig. 6. BOD (biochemical oxygen demand) (A), COD (chemical oxygen demand) (B), and water temperature (C) data in the Shinano-gawa River basin. BOD (A) and water temperature (C) are significantly different between the observatory sites (A: $p<0.001, \mathrm{C}: p<0.01$, Friedman test), and asterisks $(*)$ indicate significant differences $(p<0.05$, multiple comparison with Scheffe test). Black dots and error bars indicate the mean and standard error at each research site.

図 6 信浱川水系における BOD (A), COD (B), および水温 (C). A, C: BOD および水温のいずれについても, 観測所 間での有意な違いが認められ（A: $p<0.001, \mathrm{C}: p<0.01$, Friedman test), Scheffe 法による多重比較で有意な違い が認められた観測所間については*で示す $(p<0.05)$. 黒点およびエラーバーは平均值および標準偏差を示す.

ものの, 犀川の小市橋観測地点の BOD 值は千曲橋観測 地点より有意に低い值であった。

千曲川および姩川の各観測地点間における水温測定 データには有意な違いが認められたものの $(p<0.01$, Friedman test), Scheffe による多重比較ではいずれの観測 地点間においても有意な違いは認められなかった（Fig. $6 \mathrm{C})$ 。

\section{考 察}

千曲川におけるオオシロカゲロウの分布域は, 従来 考えられていたよりも広く, 少なくとも上田橋から小布 施地区までの間に分布しており, 中村 (1999) の調査で は成虫が確認されなかった姩川の流入点よりも下流側に も幼生が分布していることが明らかとなった（Fig. 1, 35)。ただし, 本調査では分布の上・下限が明らかになっ 
ていないため，本調査地域より上流や下流側においても 分布する可能性がある。

平和橋地区から粟佐橋地区では幼生の体サイズは大き く, 高い現存量と個体密度が認められており, 好適な八 ビタットがあるものと考えられる（Fig. 4, 5)。また，粟 佐橋地区より下流へ向からにつれて体サイズが小さくな る傾向が認められた（Fig. 4D, 5)。水温は幼生の成長率 に影響を与えると考えられるが，調査地区間での違いは 認められず，幼生の体サイズの低下は水温によるもので はないと考えられる (Fig. 6C)。オオシロカゲロウ幼生 は，デトリタスを餌とする滤過食者であり（野崎，1983; 蓮田, 1989), 富栄養な河川を好むと考光られる。本種 の分布が認められた上田-須坂市間では，BOD やCOD が下流域 ( 新潟市) と同様に高い数值を示すことが報告 されている（国土交通省北陸地方整備局，1997; 沖野ら， 2006)。一方，姩川と合流することにより BOD や COD 值は低下することが言われている。2005 年の BOD や COD 值のデータからも上田-須坂市間で高く, 姩川との 合流で低下する傾向が認められた（Fig. 6)。千曲川の中 流域では，上田市をはじめとする流域市町村から栄養塩 類が流入するため, 付着藻類の現存量が高いことが報告 されているが ( 沖野ら, 2006), 平和橋や粟佐橋地区の ような富栄養な河川地区では, 餌となるデトリタスが豊 富に存在するため, 幼生は高い成長率で成長することが できると推察される。屋島橋や小布施橋地区では比較的 貧栄養な犀川の合流により慨不足を生じてしまい, 幼生 の成長率の低下を引き起こしてしまうのかもしれない。

しかし，上田橋から下流へ向からほど増加する幼生の 体サイズや現存量は，犀川の入点よりも上流側の岩野橋 地区から低下する傾向が認められており，粟佐-岩野橋 地区間に該当する千曲橋-関崎橋観測地点間では，BOD やCOD 值に大きな違いは認められなかった（Fig. 6A， B)。したがって，幼生の体サイズや現存量の低下の原 因は犀川合流の影響だけではないと考学られる。粟佐一 岩野橋地区間は, 扇状地帯 ( 上田-粟佐橋地区) から自 然堤防帯に移行する地形に該当している（国土交通省北 陸地方整備局, 1997)(Fig. 1)。オオシロカゲロウ幼生は, こぶし大程度のはまり石のある河床にU字型の巣を堀っ て潜る，いわゆる掘潜型のカゲロウである（蓮田 , 1989; Ban et al., 1994)。平和橋や粟佐橋地区は扇状地末端部で あり, 千曲川の大きな湾曲部に位置するため, 慨となる デトリタスをはじめ, 幼生が好むこぶし大程度の中砶や, 間隙を形成するための土砂などが多く供給されると考え られる。一方，千曲川の大きな湾曲が終わり，河川勾配
も緩やかな自然堤防帯に移行した岩野橋地区では, 供給 される堆積物, 特にこぶし大程度の石の供給が減少する ため, 底質が細かくなり (Fig. 3C), 幼生にとっての八 ビタットの質が低下した可能性が考えられる。また, 幼 生の個体密度が再び増加する屋島橋地区は千曲川の自然 堤防帯であるが，扇状地末端部を流れた犀川の流入直後 でもあるため, 犀川から本種の生息に適したサイズの石 が再び供給され, 適したハビタットが多く生じるのかも しれない。しかし, 水質は比較的貧栄養であるため体サ イズは小さく，利用空間が体サイズの大きい個体に比べ て小さくて済むため, 高い個体密度が認められたと推察 される。

平和橋地区や粟佐橋地区における集中的な分布につい ては，中村（1999）における成虫の発生量の結果と矛盾 しないが，上田橋地区や鼠橋地区などの上流側における 幼生の個体密度は比較的低く評価された（Fig. 1, 4, 5)。 今回の調査では, 立ち入ることが可能な範囲でしか調査 できていないため, 河川の流心部分については評価でき ていない。また，オオシロカゲロウのメス個体では，羽 化後に再度脱皮することなく亜成虫のまま産卵のための 遡上飛行 (卵や幼生期における流下を補償するための飛 行 ）をすることが知られるが，個体密度の高い平和橋や 粟佐橋地区由来のメス覀成虫が遡上飛行することで, 上 流側の万葉橋や鼠橋, 上田橋地区にまで移動することも あるのかもしれない。

姩川の入点よりも下流側の流程では, 中村（1999）の 調査において羽化個体が目撃されていなかった。オオシ ロカゲロウの羽化時期は短く同調的であるが，体サイズ の小さな個体の羽化は羽化時期の比較的後半に生じると されており（渡辺ら，1993; Watanabe et al., 1998), 調査 時期に羽化していなかった可能性が考えられる。また， 遡上飛行による影響や橋上に設置された照明の強度およ び水面からの設置距離（高さ）による影響もあるかもし れない。下流側ほど羽化成虫の体サイズが小さく, 羽化 時期が遅れるのかどらかについては, 今後の課題である。

\section{謝 辞}

本調査研究に際し, 河川生態学術研究会千曲川グルー プ ( 中村浩志代表 ) の皆様, および国土交通省千曲川工 事事務所の皆様, 信州大学理学部物質循環学科の戸田任 重教授, 兵庫県立大学環境人間学部の片野泉准教授, 独 立行政法人農業生物資源研究所の畠山正統主任研究員, 信州大学東城研究室の方々にご協力頂いた。また, 本研 
究においては, (財) リバーフロント整備センター研究 助成金, JSPS 科研費（\#21-7173, \#23-7977, KS), 信州大 学山岳科学総合研究所重点研究費からの助成も頂いた。 ここに深謝申し上げる。

\section{引用文献}

Bain, M. B., J. T. Finn and H. E. Booke (1985): Quantifying stream substrate for habitat analysis studies. North American Journal of Fisheries Management, 5: 499-500.

伴幸成 (1997): アミメカゲロウの発生に対するダム・堰 堤の影響. TaKaRa ハーモニストファンド, 平成 8 年 度研究報告 : 35-44.

Ban, Y. and CHUBU aquatic insects research group (1994): Life history and habitat preference of the burrowing mayfly, Ephoron shigae Takahashi (Ephemeroptera: Polymitarcyidae) in the Yahagi River in central Japan. Verhandlungen der Internationalen Vereinigung für Theoretische und Angewandte Limnologie, 25: 2468-2474.

千葉克彦 (2000): 長良川下流部で確認されたアミメカゲ ロウの大発生. 兵庫陸水生物, $51 \cdot 52: 227-231$.

千葉克彦 (2010): 河口堰上流で集団発生したオオシロ カゲロウ. 長良川下流域生物相調査報告書, 2010-11: 110-117.

蓮田裕一 (1989): アミメカゲロウ幼虫の生態. インセク 卜, 40: 12-18.

Inoue, M. and S. Nakano (1998): Effects of woody debris on the habitat of juvenile masu salmon (Oncorhynchus masou) in northern Japanese streams. Freshwater Biology, 40: 1-16.

Ishiwata, S. (1996): A study of the genus Ephoron from Japan (Ephemeroptera, Polymitarcyidae). Canadian Entomologist, 128: 551-572.

国土交通省北陸地方整備局（1997): 千曲川・犀川の河道 特性 一川の流れのしくみ一. 国土交通省北陸地方整備 局, 長野.

中村和夫 (1985): アミメカゲロウの卵の発生条件.イン セクト, 36: 83-86.

Nakamura, K., S. Tsurumaru, and K. Kawamura (1999): Effects of temperature and light on the embryogenesis of genus Ephoron mayflies (Insecta: Ephemeroptera, Polymitarcyidae). Proceedings of the Arthropodan Embryological Society Japan, 34: 11-16.

中村浩志 (1999): 千曲川の自然. 信濃毎日新聞社, 長野. 野崎隆夫 (1983): 相模川に生息するアミメカゲロウの生
態.神奈川自然誌資料，4: 37-41. 沖野外輝夫・河川生態学術研究会千曲川グループ (2006): 洪水がつくる川の自然.信濃毎日新聞社, 長野. 関根一希・東城幸治 (2008): メスだけで世代を繋ぐ千曲 川産オオシロカゲロウ . New Entomologist, 57: 57-64.

Sekiné, K. and K. Tojo (2010): Automictic parthenogenesis of a geographically parthenogenetic mayfly, Ephoron shigae (Insecta: Ephemeroptera, Polymitarcyidae). Biological Journal of the Linnean Society, 99: 335-343.

関根一希・鶴田大三郎・東城幸治 (2007): 多摩川水 系・日野用水におけるオオシロカゲロウ（カゲロウ 目・シロイロカゲロウ科) の生活史. 陸水学雑誌, 68: 253-260.

塩山房男 (1978): アミメカゲロウの大量発生 .インセク 卜, 29: 1-6.

東城幸治・松元篤志・牧岡俊樹 (2002): オオシロカゲ ロウEphoron shigae (Takahashi)（昆虫綱：カゲロウ 目・シロイロカゲロウ科) の生殖様式 一個体群間で の単為生殖能力の差異についてー. Proceedings of the Arthropodan Embryological Society Japan, 37: 53-56.

Tojo, K., K. Sekiné and A. Matsumoto (2006): Reproductive mode of the geographic parthenogenetic mayfly Ephoron shigae, with findings from some new localities (Insecta : Ephemeroptera, Polymitarcyidae). Limnology, 7: 31-39.

渡辺直 (1996): 大発生するオオシロカゲロウ. 海洋と生 物, 107: 424-428.

Watanabe, N. C. and S. Ishiwata (1997): Geographic distribution of mayfly, Ephoron shigae in Japan, with evidence of geographic parthenogenesis (Insecta: Ephemeroptera: Polymitarcyidae). Japanese Journal of Limnology, 58: 15-25.

Watanabe, N. C. and A. Ohkita (2000): Life cycle and synchronization of nymphal development of the mayfly Ephoron shigae in Japan (Ephemeroptera : Polymitarcyidae). Aquatic Insects, 22: 108-121.

Watanabe, N. C., I. Mori, and I. Yoshitaka (1999): Effect of water temperature on the mass emergence of the mayfly, Ephoron shigae, in a Japanese river (Ephemeroptera : Polymitarcyidae). Freshwater Biology, 41: 537-541.

渡辺直 - 中村和夫 -八田耕吉 - 久枝和生 - 石綿進一 星一彰 (1993): カゲロウ類の大量発生機構に関する研 究.日産科学振興財団研究報告書, 16: 151-162.

Watanabe, N. C., K. Hatta, K. Hisaeda, K. Hoshi, and S. Ishiwata (1998): Seasonal and diurnal timing of emergence 
関根一希ほか

of Ephoron shigae (Ephemeroptera: Polymitarcyidae) from four Japanese rivers. Japanese Journal of Limnology, 59: 199-206.

\section{脚 注}

*オオシロカゲロウのメスは亜成虫ステージで交尾・産 卵を行い, 成虫への脱皮を行わない（メス亜成虫の体 内には成虫のクチクラ分泌がなされているため, 交尾・ 産卵するステージであっても成虫とは区別して, 一般 には亜成虫として扱われている） 